\title{
The Influence of the Quality of Service and the Implementation of the Policy of Return Administration at Inpatient Room Towards Satisfaction of Third Class of BPJS Patient in Muhamadiyah University Hospitals at Malang
}

\author{
Maria $^{1}$, Byba Melda Suhita ${ }^{2}$, \\ Yuly Peristiowati ${ }^{2}$ \\ ${ }^{1}$ Magister of Health Study \\ Program of Institut Ilmu \\ Kesehatan STRADA Indonesia \\ ${ }^{2}$ Lecturer of Institut Ilmu \\ Kesehatan STRADA Indonesia
}

Email:

mariaanastasia2473@gmail.com

Received: October 12, 2019

Accepted : February 13, 2020

Published : May 11, 2020

\section{ABSTRACT}

The purpose of this research was to analyze the influence of the quality of service and the implementation of the policy of return administration at inpatient room towards satisfaction of third class of BPJS patient at RS UMM. Design of this research are analysis crossectional. Variable of the research are. the influence of quality of service and the implementation of the policy as the independent variable and patient satisfaction as the dependent variable BPJS. Population research namely inpatients who have been allowed to return home on October 15 - November 15, 2018 by the physician in question at the time when the last doctor's visit. Samples taken by random sampling technique as much as 92 respondents. The data collected by the instruments and questionnaires processed in coding, editing, tabulating and scoring as well as tested with linear regression test.

Linear regression results indicate that partially and the simultaneous values of $\mathrm{p}$ values there are shows so that $0.05<$ influence the quality of services and the implementation of the policy to the satisfaction of the patient. he value of the coefficient of determination shows the value that shows contributions from 0.434 independent variable (the quality of service and policy implementation) amounted to $43.4 \%$, while the remaining $56.6 \%$ in influence by other factors not present in the model This research. This happens because the factor that affect patient satisfaction is not only seen from the implementation of policies and the quality of services, but there is another factor that could affect such facilities or the attitude of the officers. Quality of service and implementation of the return of the patient affect the satisfaction of the patient. This happens because with the delay time return for the patient, or the patient's waiting too long is also the process of their return would cause a negative perception of the patient so that the patient feels accepted slow service.

Keywords: Service quality, implementation of policy, patient satisfaction 


\section{INTRODUCTION}

The hospital as one of the health care facility has a very strategic role in an attempt to speed up the degree of public health Indonesia. The Government has fervently and continuously strive to improve the quality of service is good which is promotif, preventive, curative, and rehabilitative programmes. Hospital Muhammadiyah University of Malang (RS UMM) is a hospital which was founded on August 17, 2013 and was owned directly by Muhammadiyah University of Malang. RS UMM is a Hospital grade $C$ in accordance with a decision of the Minister of health the number of HK. at 02/I/2560/2014 class assignment about RS UMM (Appendix 5). Types of services at the HOSPITAL emergency service is UMM, outpatient, inpatient, and medical support. The number of labor force in the RS UMM as much as 398 people, made up of the directors of 3 people, medical personnel nursing personnel 67 people, 144 people, midwifery personnel 10 people, medical support personnel and 75 non medical personnel 19 people. The HOSPITAL has a bed capacity of UMM (TT) as much as $138 \mathrm{TT}$. When viewed from the Hospital performance indicators, the achievement of the BOR (Bed Occupancy Rate) at RS UMM has increased each year and in the year 2017 has reached the standard of health of the Republic of Indonesia year $2012(60 \%-80 \%)$, that is $80 \%$. The figure refers to the utilization of inpatient services at RS UMM have reached the standard of value of efficiency.

Complaints that appear to happen due to the request of the patient's health care. Demand good service not only to medical services, but the service of the Administration, financial management and supporting elements non medical (Mulyono 2002). The patient is one of the indicators and the sign of the dissatisfaction of services RS UMM. Discontent against the Ministry caused by internal and external factors. Internal factors include the service of doctors, nurse service, speed of service, support and administration. External factors are factors that affect the use of the services and includes a geographic factors, such as the distance of the place of service, patient transportation, tariffs, and opening hours (Supriyanto \& Ernawati 2010).

Patients who are in no mood to complain that his discontent to others that eventually formed the perceptions of others towards the quality of inpatient services at RS UMM overall. Data obtained 85\% mention that information regarding the administration of the return of the patient or the patient's home a different time with the time back home. The average gained from interviews with patients going home, it takes hours for the completion of the administration of 3-4 patients home. On the basis of Kepmenkes No. 129/MENKES/SK/II/2012 concerning the minimum service standard hospitals, the speed of time administering inpatient billing information 2 hours. Inpatient billing information includes all bills which have been given services. The speed of time administering inpatient billing information is initiated from the patient can go home by doctors revealed up to billing information received by patients.

Implementation of policies rumahs akit about the return of the patient's insufficient due to many factors, obstacles faced by RS UMM is of limited human resources, it can be seen with special administrative separation yet treatment rooms with nursing tasks, so that the workload of nurses. It is necessary to further research about the keberpengaruhan quality of service based on complaints last year that already formed opinions on the implementation of the policy, or community hospitals that have not been fullest thus causing a decrease in the number of patients who use the services of BPJS at RS UMM

Based on the explanation on the background above, researchers interested in conducting research with the title influence of quality of service and the implementation of the policy of the administration of the hospital inpatient patients return towards the satisfaction of BPJS patients Class III RS UMM.

\section{METHODS}

Design of this research are analysis crossectional. Variable of the research are. the influence of quality of service and the implementation of the policy as the independent variable and patient satisfaction as the dependent variable BPJS. Population research namely inpatients who have been allowed to return home on October 15 - November 15, 2018 by the physician in question at the time when the last doctor's visit. Samples taken by random sampling technique as much as 92 respondents. The data collected by the instruments and questionnaires processed in coding, editing, tabulating and scoring as well as tested with linear regression test. 
Assessment item used in this research for each variable that is menggunkana penilaia the scale likert as follows :

$$
\begin{aligned}
& 1=\text { Very Disagree } \\
& 2=\text { Disagree } \\
& 3=\text { Agree } \\
& 4=\text { Very Agress }
\end{aligned}
$$

\section{RESULT}

\section{1) Parsial Analysis}

Table 1. Liner regersi analysis of partially (test $t$ test) the influence of the quality of service and policy implementation against the patient's satisfaction in RS UMM November 2018 (n = 92)

\begin{tabular}{lcc}
\multicolumn{1}{c}{ Criteria } & $\mathrm{t}$ test value & $\mathrm{P}$ value \\
\hline Service Quality & 4,659 & 0.000 \\
\hline Policy Implementation & 5,153 & 0.000 \\
\hline
\end{tabular}

Based on the results in table 1 shows that the value of $p$ is the second independent variable value (quality of service and policy implementation) less than 0.05 so that partially independent variables themselves (or the quality of service and policy implementation influence of patient satisfaction).

\section{2) Simultaneously Analysis}

Tabel 2 Multivariate Analysis simultaneously or synchronously to the influence of the quality of service and policy implementation against the patient's satisfaction in RS UMM November $2018(n=92)$

\begin{tabular}{llrrrrr}
\hline Model & & Sum of Squares & df & Mean Square & F & Sig. \\
\hline 1 & Regression & 20.780 & 2 & 10.390 & 34.149 & $.000^{\text {b }}$ \\
& Residual & 27.079 & 89 & .304 & & \\
& Total & 47.859 & 91 & & & \\
\hline
\end{tabular}

a. Dependent Variable: Satisfaction

b. Predictors: (Constant), Policy Implementation, Service Quality

Based on the results in table 2 show that the significance of value shows the value $=0.000$ which means less than 0.05 so that it can be expressed simultaneously or synchronously independent variable (the quality of service and policy implementation) influence of patient satisfaction.

3) Determination Coefficient Analysis

Table 3 Analysis of coefficient of determination of the influence of the quality of service and policy implementation against the patient's satisfaction in RS UMM Hapless November $2018(n=92)$

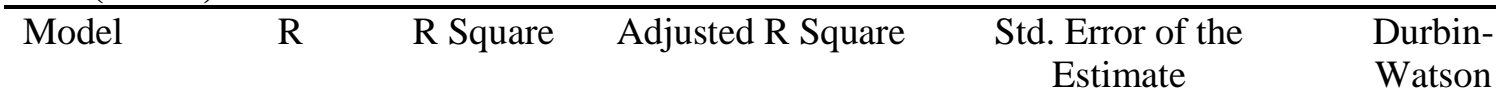

\begin{tabular}{llllll}
\hline 1 & $.659^{\mathrm{a}}$ & .434 & .421 & .552 & 1.229 \\
\hline
\end{tabular}

Table 3 explains that the value R Square (R2) are 0,434 or $43.4 \%$ indicating the contribution of independent variables (the quality of service and policy implementation) while the remaining $56.6 \%$ in influence by other factors not present in the model This research. Multiple correlation coefficient is used to measure the keeratan relationship between the dependent and independent variables. Multiple correlation coefficient indicated by value (R) 0.659 or $65.9 \%$ or indicating that the independent variable (the quality of service and policy implementation) towards the satisfaction of patients have close links. 


\section{DISCUSSION}

\section{A. The service quality Inpatient BPJS class III at Muhamadiyah University Hospitals Of Malang}

The characteristics of service quality data obtained almost half of respondents said the quality of service including hospital services that are quite as much as 45 respondents (49\%) and a small percentage of declared quality of service including good quality as many as 20 respondents $(22 \%)$. Quality of service is the goal of an agency or institution. The quality or the quality of service provided through a good management approach into the main requirement that should not be overlooked if a service provider wants to stay can be developed and developing, the increasingly tight competition nowadays makes an institution service provider or the service seeks to be able to provide a service or services to consumers with service excellence and best (Assauri, 2013). Quality of service is an activity that is carried out to evaluate the suitability of a given service provider against the expectations of the consumer (Lewis and Bloom in the Krishna rises, 2013). The implications of the quality of service, both to poor quality of service depend on the ability of service providers meet customer expectations consistently. To be able to manage the products or services with quality, then the company should pay attention to five gaps relating to the causes of the failure of the company (Lupiyoadi, 2013).

The results showed that many patients who claimed the services they receive is a quality service quite good. This happens because the respondent had enough understanding of how pelayannan to do hospital officials especially nurses on class III BPJS participants so that the patient feels accepted service already is quite good as the officer can Describes information about the State of illness experienced by the respondents and the actions that are performed by nurses or doctors in performing the handling of patients, so patients can receive information clearly and can be memehami such information, in addition to officers are also quite friendly in conveying information or skilled in performing actions in accordance with its task of each.

The existence of the respondents stating less hospital services lies in the dimension of reliability this happens because there are respondents who are still considered officers less skilled and less friendly in providing services as well as officer less clear in providing information to the patient. Additionally, on condition the tangible as hygiene lantari and the room is lacking so that patients are not comfortable with the circumstances.

\section{B. Policy Implementation at Muhamadiyah University Hospitals Of Malang}

The results of the research conducted in the policy implementation at Muhamadiyah University Hospitals Of Malang of the hospital administration about the return of inpatients BPJS class III in the policy Characteristics data obtained at Muhamadiyah University Hospitals Of Malang implementation of hospital data obtained most of the respondents said the policies being made is just right as much as 74 respondents $(80 \%)$ and a small percentage of respondents said less precise as much of the 18 respondents (20\%).

On the basis of Kepmenkes No. 129/MENKES/SK/II/2012 concerning the minimum service standard hospitals, the speed of time administering inpatient billing information 2 hours. Inpatient billing information includes all bills which have been given services. The speed of time administering inpatient billing information is initiated from the patient can go home by doctors revealed up to billing information received by patients. According to Adriani (2012) administration of hospitalization is an activity that performs the payment details medical and nursing actions, service of medicine, supporting facilities, as well as the facilities of the hospital received patients. In addition Adminstration inpatient activity also includes checking the completeness of the file related to payment processing service of hospitalization of patients. Inpatient administrative service can build a good image of hospital because patients and families communicate with the Administration before and after getting the service in a maintenance room. Bitner (1990) as quoted by Anggita (2012) describes the impact of waiting times patient satisfaction obtained against that patient satisfaction is not only influenced by the length of the waiting time, but is also influenced by the expectations of the customer in the waiting time and the cause of the length of waiting The results of this research show that the implementation of the policy of the Administration about the return of the hospital inpatient already applied appropriately by the officer so that the process 
of the return of the patient is not too long and not through a lengthy process. The presence of the patient's convenience in conducting the administrative process of return easily to make patients feel comfortable in accepting service of the hospital, and make the respondent not queued or waiting too long to immediately return home. These processes affect the desire of the respondent to tetpa using the services of the hospital concerned.

The existence of the respondents stating that service of process is less tepta happens because there is still a long and convoluted process of hospital in return patients, such as dispensing home who queued for too long in pharmacies because inpatient pharmacies still the one with public pharmacies so that patients waiting for a cure.

\section{Satisfaction of BPJS patient third Class at Muhamadiyah University Hospitals Of Malang}

Characteristics of patient satisfaction indicate that most respondents feel quite satisfied as much as 41 respondents $(45 \%)$ and a small percentage of dissatisfied by as much as 17 respondents (18\%). Customer satisfaction is the central concept of target marketing. So all the marketing planning and program a company aims to satisfy customers. Because customers will pay attention to the quality of service that was provided to the company (Laurent, 2005). Someone's feelings is the level of satisfaction after comparing performance or perceived results in accordance with the expectation (Supranto, 2012).

The results of this study indicate that many patients feel satisfied on Ministry received patients mainly on skills and response officers provided officers in response to patient complaints, other than that the officer also hospitable to the patient so that the patient feels comfortable in receiving services provided by the officer. According to the clerk at RS patients UMM always appropriate in providing the information and therapies on patients and they did not wait for the patient to menginggatkan time to visits and drug-taking. In addition the patient felt the officers take better care of patients for example they always invite the patient speak when giving therapy so that susaana becomes not the tense and administering the therapy to be smooth. Whereas in patients who feel less happens because still there are respondents who consider the less friendly nurses, nurses there is that distinguishes the awarding of services to patients with other patients, while giving the therapy they look stiff as well as the response provided appears still a long time.

\section{Influence OF Service Quality Againt Patient Satisfaction}

Based on the results in table 1 shows that the value of $p$ is the second independent variable value (quality of service and policy implementation) less than 0.05 so that partially independent variables themselves (or the quality of service and policy implementation influence of patient satisfaction). On the value of the variable quality of service value $p=0.000$.

Quality of service is very important in realizing customer satisfaction. In an environment that is increasingly full of competition, especially health services agency Clinics which is the first Ministry of health problems in the community against must be increasingly aware of the importance of providing quality the best services for its customers. The increase in the health service is very important to be made by health care provider institutions such as clinics in order to improve patient satisfaction. Patient satisfaction is the level of one's feelings after comparing the performance of the patient experience with the hope that patients want when intending to seek treatment. If the patient feels satisfied, this greatly affect an action based on the past experiences where they won't be easy to switch services because the stimulation of marketing (Yulfita, 2016). This adult look health facilities continue to strive to develop, in terms of both infrastructure capacity, along with the development of technology. Although there are developments from time to time, but the basic functionality remains unchanged. The basic functions of health facilities is the promotion and restoration of health of members of the public, whether in inpatient services. as well as outpatient consultation, as well as maintenance or health care community members (Kuncoro,2010).

The results of this research show that service quality affects the incidence of patient satisfaction in the process of the reception service at the hospital. The quality of service has the most influential dimensions and different every patient. This happens because the dimensions of patient service given by different ways and skills in providing services officer is also different that this affected 
the perception of the patient in receiving health care services. The quality of service that is still less lies in the dimension of reliability this happens because the respondents still consider that less skilled officer in carrying out the Act, officers of the less friendly in providing service and the officer less clear in providing information to the patient.

\section{E. Influence of Policy Implementation agint Patient Satisfaction}

Based on the results in table 1 shows that the value of $p$ is the second independent variable value (quality of service and policy implementation) less than 0.05 so that partially independent variables themselves (or the quality of service and policy implementation influence of patient satisfaction). On the value of the variable value $p=0.000$ policy implementation.

Administrative service for the repatriation of patient hospitalization, one of which is influenced by the policy of the hospital as a system. Approach system can be used as a tool to find out the factors that are not fixed, barriers, and ineteraksi. The system is made up of parts which are interconnected and affect (Anggita 2012). The system is a combination of elements that are connected by a process or structure and function as one unified organization in an attempt to produce something that is applied (Kemenkes 2012). The delay time of home hospitalization of patients because of the slowness of administrative settlement process had an impact on the length of time waiting for the return of the patient. Patients can complete the administration of the inpatient in order to home takes a 3-4, good public patients, BPJS, or private insurance. Long waiting time can change the perception of the quality of service will be RS patients UMM, especially for inpatients who want a quick resolution of the administrative process (O'Connel et al. 2008; Zeitz \& Tucker 2010).

The administrative process of the return of the patient will affect patient satisfaction because if the process of the return of the patient for too long or the patient's return is delayed, the pasine will feel less satisfied in accepting service of the hospital, as it should when the patient had already been allowed to return home by doctors they wanted to immediately come home and meet with families at home. However, if the process of the return of the patient pending they will feel uncomfortable so that it affects patient satisfaction in receiving hospital service.

\section{F. Influence of quality of pelayann and implementation of the policy against the patient's} Satisfaction

Based on the results in table 2 shows that the value of $p$ is the second independent variable value (quality of service and policy implementation) less than 0.05 so that partially independent variables themselves (or the quality of service and policy implementation influence of patient satisfaction). Based on the results in table 3 show that the significance of value shows the value $=0.000$ which means less than 0.05 so that it can be expressed simultaneously or synchronously independent variable (the quality of service and policy implementation) patient satisfaction. Table 4.6 describes that the value R Square (R2) of $43.4 \% 0.434$ or indicating the contribution of independent variables (the quality of service and policy implementation) while the remaining $56.6 \%$ in influence by other factors not present in the model This research. Multiple correlation coefficient is used to measure the keeratan relationship between the dependent and independent variables. Multiple correlation coefficient indicated by value (R) of $0.65965 .9 \%$ or indicating that the independent variable (the quality of service and policy implementation) towards the satisfaction of patients have close links Bitner (1990) as quoted by Anggita (2012) describes the impact of waiting times patient satisfaction obtained against that patient satisfaction is not only influenced by the length of the waiting time, but is also influenced by the expectations of the customer in the waiting time and the cause of the length of the wait. Research on the effect of waiting time on patient satisfaction sanga needed to assess objectives and perceived waiting time of patients as well as patients in the hope of waiting. The length of the waiting time in the service of the administration of the return of inpatients influenced several factors, namely: nursing actions in a maintenance room, the number of queue recipes poli and hospitalization in the pharmacy, and the number of queued files at the checkout. The delay time of the patient's return home will bring up a negative persespis of the patients about the quality of service received. 
The results of this study showed that the quality of service and kebijkan implementation of the return of the patient affect the satisfaction of the patient. This happens because with the delay time return for the patient, or the patient's waiting too long is also the process of their return would cause a negative perception of the patient so that the patient feels accepted slow service. This will affect the patient's interest in providing recommendations on other people to do the checks or receive medical services in hospitals.

\section{CONCLUTION}

1. Quality of patient service at Muhamadiyah University Hospitals Of Malang shows almost half of respondents said the quality of service including hospital services that are quite as much as 45 respondents (49\%). This happens because there are still patients who haven't felt that the Ministry provided at Muhamadiyah University Hospitals Of Malang include good service because there are still some deficiencies in the awarding of services like some officers still exist that are less friendly, and the information provided about the conditions of patients were less clear.

2. Policy implementation the hospital administration about the return of the patient at Muhamadiyah University Hospitals Of Malang most respondents said the policies being made is just right as much as 74 respondents (80\%). This happens because the management has done the study and observation of the Ministry that has been running in hospital so that management make policies in accordance with the conditions of the current hospital so that the service can run effectively and efficiently.

3. Patient Satisfaction indicate that most respondents feel quite satisfied as much as 41 respondents (45\%). This happens because the respondents felt service was given hospital had enough in accordance with the expectations of the patient though there are still some of the equipment in the performance of gan but respondents felt it was quite satisfied receiving services provided .

4. There is a partially influence the quality of service and policy implementation in the hospital with the patient's satisfaction with the value of the $p$ value $0.05<$

5. There is a simultaneous influence of quality of service and policy implementation in the hospital with the patient's satisfaction with the value of the $\mathrm{p}$ value $0.05<$

6. The value of the coefficient of determination shows the value that shows contributions from 0.434 independent variable (the quality of service and policy implementation) amounted to $43.4 \%$, while the remaining $56.6 \%$ in influence by other factors not present in the model This research. This happens because the factor that affect patient satisfaction is not only seen from the implementation of policies and the quality of services, but there is another factor that could affect such facilities or the attitude of officers

7. The dominant Factors that influence patient satisfaction is the implementation of policies that demonstrate the value of the highest B i.e. 0.782. Because with the right policy will be mevciptakan effective and efficient services and improve patient satisfaction

\section{REFERENCE}

Alexander, 2010, Analisis Kualitas Pelayanan Jasa Penginapan terhadap Kepuasan Konsumen pada Hotel Arinas di Bandar Lampung, Jurnal Manajemen dan Bisnis, Universitas Bandar Lampung Indonesia.

Anggita Subakti, 2014, Analisis Kualitas Pelayanan di Restoran Saung Mirah, Bogor, Binus Edu.

Aryani, D dan Rosinta, F. 2010. Pengaruh kualitas Layanan Terhadap Kepuasan Pelanggan Dalam Membentuk Loyalitas Pelanggan. Jurnal Ilmu Administrasi dan Organisasi.Vol.17.No.2.

Fandy, Tjiptono.2014. Manajemen Jasa. Yogyakarta : Andi.

Kotler, dan Keller. 2012. Manajemen Pemasaran. Edisi 12. Jakarta: Erlangga.

Krishna Naik. 2013. A Conceptual Analysis of service Quality in Tourism Industry. Journal of Servive Marketing. Vol 16 (4), 36379 
Lupiyoadi, Rambat. 2013. Manajemen Pemasaran Jasa Berbasis Kompetenis. Jakarta : Salemba Empat Sugiyono. 2008. Metode Penelitian Kunatitatif Kualitatif dan R\&D. Bandung : Alfabeta.

Supriyanto \& Ernawati. 2010. Pemasaran Industri Jasa Kesehatan, Yogyakarta : CV.Andi Offset William, J.Stanton. 2004. Prinsip-prinsip Pemasaran, Jakarta : Erlangga.

Yuwono, 2012, Analisis Pengaruh Kualitas Pelayanan Terhadap Kepuasan Pelanggan pada Hotel Sewu Mas di Yogyakarta. Thesis 2, Binus Library 